\title{
Students as digital multimodal text designers: A study of resources, affordances, and experiences
}

\section{Helene Dahlström (1)}

Department of Education, Mid Sweden University, Sundsvall, Sweden

\section{Correspondence}

Helene Dahlström, Department of Education, Mid Sweden University, Holmgatan 10, 85333 Sundsvall, Sweden. Email: helene.dahlstrom@miun.se

\section{Funding information}

None

\begin{abstract}
This paper addresses how students design multimodal digital text when making digital stories in school. Drawing on the perspective of 'multiliteracies', multimodal analysis of video recordings was used to understand the data. Findings revealed that (a) multimodal digital text making requires particular digital and modal text-making skills and knowledge, such as knowledge of photography, film, film editing, image searching, and audio recording; (b) students' prior knowledge was crucial for mastering the digital and modal affordances offered when making digital stories; and (c) making multimodal digital texts in school offers increased opportunities for students to perform and succeed in text making. These findings point to the need for schools to offer education that makes it possible for all students to gain knowledge and master skills needed for contemporary text making. Such knowledge goes beyond skills and practices needed when making paper-based text, and borders on other disciplines such as art and technology.
\end{abstract}

\section{KEY WORDS}

design process, digital text making, multiliteracies, multimodal composing, students

This is an open access article under the terms of the Creative Commons Attribution-NonCommercial License, which permits use, distribution and reproduction in any medium, provided the original work is properly cited and is not used for commercial purposes.

(c) 2021 The Authors. British Journal of Educational Technology published by John Wiley \& Sons Ltd on behalf of British Educational Research Association 


\section{Practitioner notes}

What is already known about this topic

- Text making in the 21st century entails working in various modes, such as images, writing, and video, and is often performed with digital resources.

- Today's students must be competent in designing multimodal texts that are commonly associated with digital technology and multimedia.

- Students' modal choices when creating digital texts are influenced by prior experiences and knowledge of text-making practices obtained outside school.

What this paper adds

- This paper provides examples of the differing prerequisites of students designing a digital multimodal story.

- This paper offers insights into the particular digital and modal text-making skills and knowledge necessary for students to become competent text makers.

- Multimodal digital texts activities in school offers increased opportunities for students to perform and succeed in text making.

Implications for practice and/or policy

- The results of this study have implications for literacy practices as well what is included in the literacy curriculum. This study provides implications for education that intends to reduce inequalities in students' prerequisites concerning making digital multimodal texts, and examines the text-making experiences, knowledge, and skills students already possess upon entering the classroom.

- Classroom-based instruction and opportunities for digital creation can bridge the gap between student's informal text-making activities and formal text-making activities at school and help to close the digital divide among students.

\section{INTRODUCTION}

The media environment of contemporary children is dramatically different from that of just a few decades ago. Text making in the 21st century is about working in various modes and media, including images, writing, and video, and is performed with print-based as well as digital resources (Jewitt, 2012). In this paper, the term 'digital multimodal texts' refers to texts that include several modes (Kress, 2010) and are produced digitally (Jewitt, 2012). When creating digital texts, students' modal choices are influenced by previous experiences and knowledge of text-making practices obtained outside of school (Kress, 2010; Pahl \& Rowsell, 2019). Learning is thus described as social and meaning-making activities that can occur anywhere and at any time, and meaning-making is defined as an activity in which individuals try to understand the world (Bezemer \& Kress, 2016). Despite the younger generation's increased use of digital resources, students have diverse backgrounds and thus diverse experiences and access to literacy, texts, and digital resources (Jewitt, 2012; New London Group [NLG], 1996). Not having access to specific resources (e.g., digital resources commonly used in communication, representation, and socialisation) leads to risks of marginalisation. An individual who does not have access to resources is then without access to cultural arenas or social fields, and the lack of digital experiences can be confused with an individual's lack of competence or ability (Hernwall, 2010). Therefore, it becomes crucial for schools to create possibilities for all students to learn how to communicate in the society where they play an active part, including by enabling students to understand digital media and their use. We know from previous research that multimodal text composition requires 
that students have prior knowledge of digital multimodal authoring, and can master technology, as well as having knowledge of the processes required to produce innovative digitalmedia productions (Bezemer \& Kress, 2017; Mills, 2010). To advance this area of enquiry, this paper reports on research conducted in Sweden regarding how students design text and what digital and modal resources they use in the process.

Research has found that digital resources greatly influence the process of designing texts (Björkvall \& Engblom, 2010; Edwards-Groves, 2011; Mills, 2011; Smith, 2017; Sofkova Hashemi, 2018; Svärdemo Åberg \& Åkerfeldt, 2017). Additionally, research on students' multimodal meaning-making in informal environments has highlighted the importance of linking informal text activities with school text activities (Bezemer \& Kress, 2017; Gee, 2004; Jewitt, 2009). There are didactic challenges for schools in meeting and assessing new conditions for text creation, indicating that there remains much to learn before schools have fully adopted new ways of creating and assessing texts (Edwards-Groves, 2011; Jewitt, 2009; Shanahan, 2012). Finally, research suggests that there exists a digital inequality among students, with some students developing considerable digital skills and knowledge by participating in supported activities at home, while others have little or no opportunity to engage with digital tools (Author; OECD, 2015; Ritzhaupt et al., 2020; Samuelsson, 2014). As a result of the lack of access and regular use of digital resources, students may not fully benefit from education (Ritzhaupt et al., 2020). According to the OECD (2015) and Auxier and Andersson (2020), a gap exists among students concerning access to digital tools due to socioeconomic background. However, access to digital tools is only one of many factors required to make good use of digital resources and reduce inequality (Auxier \& Andersson, 2020; OECD, 2015). Technological and social changes have resulted in new text-making conditions and require new competencies in addition to the competencies of traditional forms of reading and writing (Bezemer \& Kress, 2017). Therefore, they argue, there is a pressing urge for expanding our understanding of how young people design texts.

This study extends the research on digital multimodal text-making by considering how students design digital text and what skills, knowledge, and resources they use in the process. Such knowledge, in turn, offers indicators of skills and knowledge needed for digital multimodal authoring and can provide with pedagogical implications for literacy education.

The following research questions guided the study:

- What digital and modal resources are employed in students' text design processes?

- What motivates students' choices of resources?

- What affordances and constraints do digital and modal resources offer students when designing text?

\section{MULTILITERACIES}

This paper derives from a 'multiliteracies' perspective, in which meaning-making is central and is seen as a multimodal design process (Kress, 2009; NLG, 1996). The prefix multi-, in multiliteracies, refers to plurality, and involves several meanings. Firstly, people often engage in a plurality of literacy activities according to the affordances offered by digital resources; secondly, plurality refers to the multiple ways in which meaning is created. Furthermore, in the multiliteracies perspective, literacy is seen as embedded in social practice and includes diverse texts and technologies (Cope \& Kalantiz, 2015). Multiliteracies research has contributed to the field of literacy by redefining what it means to be literate in contemporary society (Mills, 2016; NLG, 1996; Olthouse, 2013). Besides printed or written forms of language, literacy has been broadened to include multiple modes of representation, such as music, gestures, and pictures (Cope \& Kalantiz, 2015; Olthouse, 2013). The 
perspective of multiliteracies contends that literacy is situated and has a social purpose (Cope \& Kalantiz, 2015; Olthouse, 2013). Literacy is situated since literacy practices are different in various contexts. For instance, creating text is not the same in school as in more informal settings. Further, the multiliteracies approach assumes that learning is a process of weaving, back and forth, across and between different learning practices. Such practices include learning as situated practices, overt instruction, critical framing, and transformed practices (Cope \& Kalantzis, 2015).

'Situated practices' involves building on the lifeworld experiences of students that situate meaning-making in various contexts. In other words, this involves recognizing students' life experiences even in the classroom environment. In this paper, the term could mean to recognise students' experiences of different digital resources they are familiar with, such as social media text making (Lankshear \& Knobel, 2011; NLG, 1996). 'Overt instruction' in education involves intervening to meet students' needs for necessary genre and textmaking knowledge and significant digital instruction (Ryan et al., 2010). In this paper, overt instruction relates to the need for explicit pedagogy to enhance the knowledge and skills necessary for contemporary text making. 'Critical framing' involves critical reflection on the purposes of texts and the ways that textual features reflect these purposes and should be integral to the pedagogical process (Ryan et al., 2010). Analysing critically is crucial for 21st-century students to interpret and understand the experiences of family, friends, popular culture, social media, and language in making texts (Cope \& Kalantzis, 2015; Lankshear \& Knobel, 2011). 'Transformed practice' here refers to the understanding of text making that emerges from operating in the digital and multimodal environment (Cope \& Kalantzis, 2015; Ryan et al., 2010).

\section{The multimodal design process}

Contemporary text making is rarely about using separate modes. Instead, the question when making texts is what function different modes can have in a text that consists of a combination of modes (Bezemer \& Kress, 2017). A multimodal perspective on meaning-making entails focusing on all modes involved in communication and representation (Kress, 2010). Modes are socially created and culturally given resources for meaning-making. A person's choice of modes in text design reflects historical and social contexts and former experiences (Danielsson \& Selander, 2016; Jewitt et al., 2016; Kress, 2010; van Leeuwen, 2005). An example that relates to text design may be a student whose previous experience of texts in the classroom environment is written text, and who therefore may choose writing as the mode of expression in his or her text design.

In this article, students' multimodal text making is analysed. Seeing meaning-making as a multimodal design process helps in discussion and analysis of students' meaning-making with multiple modes. The three parts involved in the design process symbolise that meaningmaking is an active, dynamic process (NLG, 1996).

The 'available design' includes the resources available when designing meaning, and includes the diverse backgrounds of learners and, thus, the diverse resources available for making meaning. All resources available for meaning-making are considered, including digital resources, pen and paper, and the various modes available (NLG, 1996). 'Designing' is a meaning-making activity. In this article, the empirical data consist of video recordings of students designing texts. Designing is about representing the world based on other people's designs (e.g., reading, listening, watching videos, or producing texts) (Cope \& Kalantzis, 2009). The 'redesigned' is a person's representation of the world and their knowledge about the world (Cope \& Kalantzis, 2009). In this paper, the redesigned is the students' texts, and multimodality can be used as an analytical tool to 
understand contemporary meaning-making. In this study, multimodality was used to understand students' choices of modal and digital resources. To analyse students' design processes, and to provide their implications for pedagogy, the perspective of multiliteracies was used.

\section{Multimodal text making in educational settings}

Despite the shift towards a pluralised view of literacy, multimodal text comprehension and meaning-making processes are still less valued in educational settings (Andersson, 2015; Mills, 2016; Author; Magnusson \& Godhe, 2019; Sofkova Hashemi, 2018; Tan et al., 2020). One explanation for this could be that, despite empirical studies suggesting that multimodal literacies practices are recognised in the classroom, there is a disjuncture between multimodal productions and assessment practices. Multimodal text comprehension and meaning-making processes remain largely under-valued and less recognised in assessment outcomes (Silseth \& Gilje, 2019; Tan et al., 2020). As a result of these assessment practices, Silseth and Gilje (2019) observe that students were less motivated in the process of creating multimodal texts, as they knew that teachers valued written productions more.

Sofkova Hasheimi (2018) is a clear example of how socio-technological changes have a role in classroom-practice change. In the study, eight-year-old students were given instructions on how to make a glove-bunny. The instructions were available in various modes and media, including video, sound, and written text. All students choose to pay attention to the filmed instructions exclusively, and the findings demonstrated that students paid attention to digitally mediated multimodal texts before engaging with written text. The teacher had to direct the students to engage with the written text to complete the instruction. However, both the written and filmed instructions contributed to the students' understanding, and it was not until they used all of the resources of both texts that students finally succeeded in following the instructions and making the glove-bunny. The study revealed the vital role of the teacher in enabling the students to use all available resources in order to completely understand the lesson. The students' various design processes were shaped by the digital tools available and their own modal preferences concerning text design. Digital multimodal text making in school can increase students' independent work as text makers, according to Flewitt et al. (2015). In students' engagement with iPad-based literacy activities, one of the findings was that multimodal digital text making sometimes brought shifts in how children were seen as text makers by their peers and their teachers. Further, findings suggested that digital devices in text-making activities opened up opportunities to redress the power balance between teachers and children, as some children were often seen as competent or even more competent than teachers, regarding handling the digital tools. In another study, fifth-grade students' design processes were analysed while creating multimodal texts (Jocius, 2017). Two of the students' processes were micro-analysed. The researcher found that one student, who identified himself as competent, preferred writing when making meaning. The student expressed that he valued writing as a mode more highly than other modes, such as image or video. In making multimodal text, he used writing as the most substantial mode to carry meaning. The other student, who identified himself as an incompetent student, was reluctant to use writing. He had extensive experience with photography and videography, however. In creating multimodal text, he was very productive and was suddenly seen as a high-performance student, whom other students could now admire, because was most knowledgeable. While carrying out this particular task in school, the two students' respective positions were reversed. 


\section{Literacy as situated practice}

Even though literacy practices in students' everyday lives are characterised by digital and multimodal text-design activities, formal literacy education lags behind contemporary practices (Bezemer \& Kress, 2017; Dalton, 2014; Nagle \& Stooke, 2016). In a case study of students' meaning-making in and out of school, Nagle and Stooke (2016) found that it is essential to create opportunities for students to make multimodal texts in school, as they already do outside of school. Students' meaning-making practices were a mix of resources from textbooks, online sites, popular culture texts, and students' literate identities. That students' texts are often influenced by social media and popular culture was also seen in the study by (Author), where students' narrative texts were analysed. Further, Nagle and Stooke (2016) noticed that the students made design choices out of an awareness of modal affordances. For example, some students created a webpage, as it offered possibilities to use multiple modes. Magnusson and Godhe (2019) conducted a study focused on students' multimodal text designs, and how multimodal meaning-making is supported in Swedish curricula. Results showed that students used various modes and media in their designs, although a multimodal approach to designing texts in the classroom was new to them, and no explicit teaching about multimodality was provided. As in studies by Smith (2017) and Sofkova Hasheimi (2018), participating students used available designs from informal settings outside school, as well as from the formal school setting. In Ryan et al. (2010), teachers reflected upon students' greater motivation to complete schoolwork in the multimodal context. The usual challenges of trying to motivate unmotivated students were reduced, and the teachers observed that students felt motivated and familiar with digital and multimodal tasks. The researchers meant that the situated practice was connected to students' interests, and therefore more motivating.

\section{Implications for pedagogy}

According to Rowsell and Walsh (2011), the multiliteracies pedagogy can provide young people with tools to understand the world and be equipped for contemporary text making. In contemporary text making, students must become fluent in using various tools and modes to design digital and multimodal texts (Dalton, 2014; Author; Sofkova Hashemi, 2018). In Dalton (2014), the participating teacher developed a strategy to give all students the scaffolding necessary to use modes and media in text making. Students were taught different modal affordances in text design, and how to use various digital resources (e.g., how to download images). Research has shown that using a multiliteracies approach to literacy in school can expand students' possibilities to complete school tasks (Drewry et al., 2019). For example, Drewry et al. (2019) examined how literacy learning could be improved for students who experienced challenges in print-based classroom activities. As a method, the researchers had developed a multimodal program in order to examine whether providing multiple ways for students to make meaning could improve students' possibilities to complete literacy activities in school. The most important finding turned out to be bridging school literacy activities with the multimodal literacy activities that students used at home. The researchers found that, when students with difficulties performing print-based school tasks were given opportunities to use digital tools, like iPads, the student's ability to complete school tasks improved. One reason for this improvement was that students felt comfortable using iPads, which were the tools they used to make meaning at home (Drewry et al., 2019).

One way of providing information regarding what students already know about digital multimodal text making, and they might need to learn in school, is to analyse young people's text-making processes. Bezemer and Kress (2017) studied how young people made text on 
Facebook and recognised some resources and principles about young people's digital multimodal text making. The analysis revealed specific competencies central to contemporary text making that could be taught in school. Examples of such competencies included writing knowledge, film knowledge, and knowledge of multimodal text composition. The multimodal design process often involves using ready-made text parts, such as images or written text. Digital resources can easily be reused with the 'copy and paste' function. The inclusion of critical reflections regarding copy and paste techniques in formal literacy education is therefore necessary (Adami, 2015). Using the multiliteracies framework, Ryan et al. (2010) studied literacy practices in order to discern whether teachers were facing particular pedagogical challenges teaching text design in digital multimodal textual environments. The researchers found that, besides instructions about technology and multimodal composition, teachers must involve critical framing as part of students' possibilities to become competent text makers. One key finding was that teachers' most important role, in the multimodal context, was to engage students in critical reflections on topics such as the use of modes and media to communicate messages.

To conclude this section, multimodal text making and literacy as situated practice in school can connect to students' interests and lifeworlds, thus motivating students (Magnusson \& Godhe, 2019; Ryan et al., 2010). Contemporary literacy practices require an understanding of the modal and digital potentials of multimodal texts (Jocius, 2017; Kress, 2010; Sofkova Hasheimi, 2018). Therefore, overt instruction and critical framing might be needed in order to give all students tools for mastering contemporary text making (Dalton, 2014; Ryan et al., 2010; Sofkova Hasheimi, 2018). Multiliteracies, as a pedagogy, can provide young people with tools to understand the world and to be equipped for contemporary text making (Drewry et al., 2019; Rowsell \& Walsh, 2011).

\section{METHOD AND STUDY CONTEXT}

The students included in this study derived from two fifth-grade classes (ages 10/11) in a school located in a multicultural suburban area in central Sweden. Multicultural, in this context, indicates that the student body includes many children who speak Swedish as a second language.

The study's sampling can be described as both strategic and convenient (Grey, 2013). It was strategic because the choice of school and students was made in line with the study's purpose, that is, to increase the understanding of middle-school students' design processes while engaged in creating multimodal digital texts in school. To achieve this purpose, it was essential to find a school that reflected the variety of students in Swedish schools, in both socioeconomic and linguistic terms.

As part of the subject Swedish, lessons were given on digital storytelling. To create texts where words, pictures and sound interact are part of the content for years 4-6 in the Swedish curriculum. Students were instructed by their class teacher to create a digital story using the same application on tablets for the task. The application used was 'Book Creator App for iPads' (C) '(www.apple.com and www.redjumper.net/bookcreator). The Book Creator app makes it possible to upload images, videos, audio, and draw, write, and create digital books. The time students had to create the stories was four two-hour lessons over two weeks.

Before starting the actual design process, students prepared for the task by discussing different kinds of stories, and when to use different modes in text design. The teacher introduced the students to the Book Creator application and described its essential functions. The application's modal resources were writing, drawing, taking photographs, downloading photos from the Internet, and recording video or audio. In the design process, students had access to the Internet to be able to download images. Within the constraints 
of the app, students were free to choose the text design and topic. The class teacher was present and offered students support when needed under the process of creating stories. While designing, all 23 students included in the study were video recorded. Students talked and discussed their modal and digital choices with the author of the present study, as well as with friends in the same room. I was present in the room the whole time, and students sat alone or with a few friends while working on their stories. This arrangement made it possible for me to talk with students and ask follow-up questions about what they did and their choices. The students designed their stories in unique ways, making it impossible to ask all students the same questions. Rather, I asked questions based on what students expressed and did in each individual case, such as, "I saw that you used images in your story, can you show me how to find them on Internet?". Questions like "how do you know what keywords to print in the search engine?" provided me with information concerning home text-making practices.

Some students spoke extensively with me and asked questions themselves, while others worked more or less in silence. The tablet was placed obliquely behind each student. This allowed both the student, and the screen, to be visible in the recording that composes the data.

The initial data set consisted of 23 video recordings of students' design processes. The recording of each student was an average of approximately 25 min long, ranging from 18 to $55 \mathrm{~min}$. From this data set, which was also used in another study with a different focus (Author), I used purposeful sampling (Grey, 2013) to choose five students for in-depth analysis of their multimodal design processes. The purpose of the sampling was to describe and analyse design processes that differ from each other, in order to obtain a picture of the variety of the student design processes present within a class.

\section{Multimodal transcription and analysis}

Using the multimodal method of video observation makes it possible to focus on students' use of different modes in their text designs in retrospect. Choosing a multimodal method is justified by the assumption that meaning-making takes place using different modes (Kress, 2010). Transcribing video material involves translating from one mode to another (e.g., from video to writing), which means choosing what of the video material is to be translated into writing, because it is next to impossible to write down all aspects of what is seen and heard in a video (Bezemer \& Mavers, 2011). The video recordings were initially viewed and coded into the multimodal transcription manual, made in advance. The transcription model, inspired by Insulander (2010), focused on students' speech, movements, images, writing, sound, and video. The transcription manual was done in columns, where time in the video and each mode occupied a separate column. When transcribing the speech mode, I wrote in the 'speech' column what was said by the student, by a friend, or by me. In the 'image' column, I wrote what was done concerning images, and so on.

The in-depth analyses of the five students' design processes started with an overall multimodal analysis, to describe which of the available resources students used in their designs (Danielsson \& Selander, 2016). The next step in the analysis was to identify themes in the multimodal data, using an abductive thematic analysis (Braun \& Clarke, 2006). Then, the data were further interpreted, concerning the concept of learning as a situated practice (Cope \& Kalantzis, 2015; NLG, 1996).

To ensure the study's trustworthiness and credibility, I aimed to be transparent in the research process and use methods that stayed close to the multiliteracies approach used in the study. 


\section{RESULTS}

The five students' design processes are presented in the following. Next, the affordances and constraints of the modes and media in the students' design processes are presented. Finally, examples of the text-making skills, knowledge, and resources that students displayed in the process are presented.

Paula (participants are identified using pseudonyms throughout) mainly engaged with the mode of writing. She created the whole story by writing. She typed fast on the tablet and used the word processing program. She is accustomed to reading and writing, and reads and writes well, she says. Paula explained that she decided to write the whole story immediately when the teacher explained the task and did not bother to try any other functions offered by the application. Paula did not use any images in her text making, explaining that she finds it difficult to search for images on the Internet. But this was not a problem since she preferred writing. As an explanation of why she preferred writing over other modes, she said:

I also do not read books with pictures, so it feels obvious that I do not use pictures when making a story. I like [it] more when you have to think for yourself, create your pictures in your head.

While Paula preferred to use the mode of writing only with the argument that it is better to create your picture than being served with pictures in the story, Johan had a different opinion:

The experience of the story will be better if you also use images in the story. It gets more exciting.

In contrast to Paula, Johan started his design process by taking photos of his friends, who became the characters in his story. The photos were used to illustrate the characters in his story. He complimented the photos with some drawings directly on the tablet to illustrate what was happening in the story. After saving the photos in the tablet's gallery, Johan started to write on the tablet. He used the mode of writing to describe some events in the story and explain who was evil and who was good in the story. For example, he wrote, "evil is the baby" He also used writing mode when naming the characters in the story.

Johan included sound effects and music in his story, using the voice recording function, and he downloaded a rap song from the Internet and composed a rap himself. He recorded the song within the recording option in the application. Finally, Johan made a short video clip where the characters (his friends) demonstrated a fight. Johan was the only student that used all the possibilities offered by the application. Figure 1 illustrates the modes used in Johan's story.

As he was composing, Johan said that he was used to using digital tools to compose text. At home, he downloaded music and made video clips to post on social media.

Fatima started the process by choosing the mode of writing. According to Fatima to create a story is to write a story. However, she said she found it challenging to produce a story, as she was a slow writer and had some difficulties with spelling. After several attempts to write a story without success, Fatima chose to use the voice-recording function. I asked Fatima if she knew what the story was about, she explained that she already had the story inside her head. The problem lay in the writing process, as she explained. So, I suggested that she could tell the story instead and use the voice recording. Then, she could tell the story instead of writing it. Using the potential to make voice recordings instead of writing enabled Fatima to produce her story, even though, according to Fatima, it was a bit like cheating. 


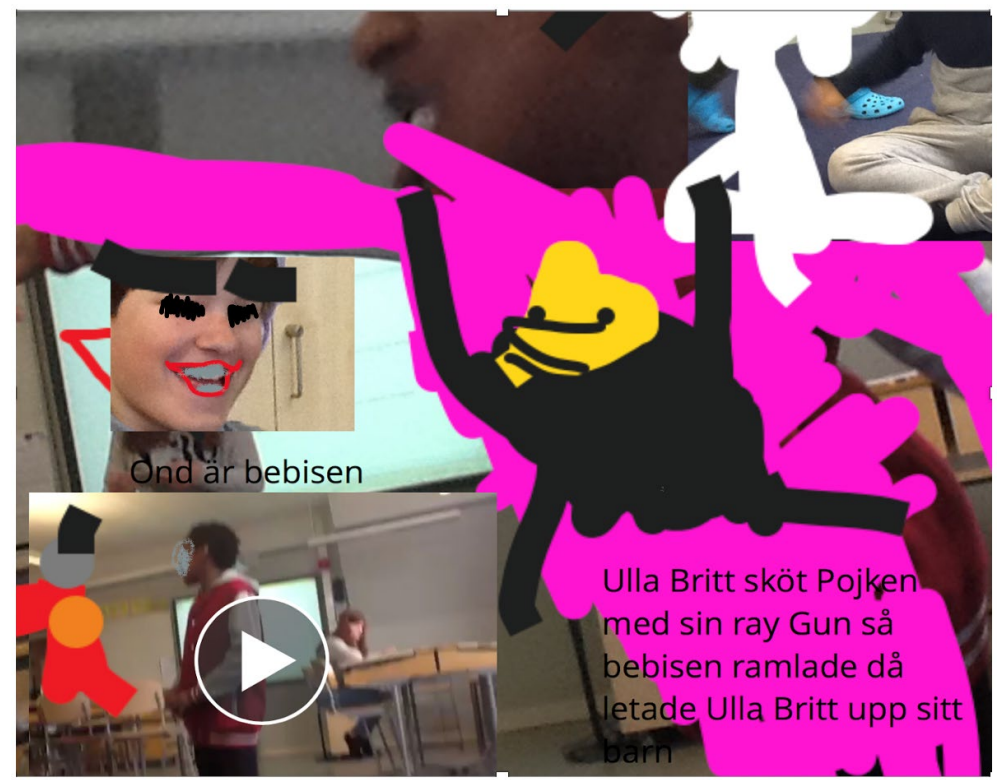

FIGURE 1 One page in Johans book

Yes, it turned out well, although it's not really okay. It's like cheating when not writing.

To illustrate the story Fatima made drawings on the tablet. She used the drawings to illustrate the horses and the mice in the story; she explained.

Ann chose yet another way to design her text. She started by drawing the whole story by hand. She made a whole story board out of detailed drawings. She explained:

When I look at the drawings, I get inspiration to write; that is how I use them.

The process was to look at all details on the drawings and then write the story. She wrote the whole story on the tablet before transferring the story to the digital format by choosing images on the Internet. After looking at her drawings, she wrote keywords from the drawings into a search engine on the Internet. She explained that she had difficulties finding images that showed what she wanted to tell in her story. Due to these difficulties, Ann decided to change her written story to fit the images that she could find. For example, in the initial story, seven girls went to a Halloween party. After finally finding a photograph of girls in costumes, the seven girls with different costumes and hairstyles became four girls who looked very similar and wore the same costume.

Figure 2 shows Ann transforming her drawings by searching and using images from the Internet.

Tiba started her design process by downloading images to the tablet from the Internet. She used images to illustrate the whole story and show what the characters and the environment looked like. She chose four to six images for each page. Then, she wrote a small text part for each page. The writing was used mainly to describe relations between the characters in the story.

When searching for images, Tiba used keywords such as "ex on the beach," "broken heart," "Justin Bieber," and "crying blue eyes." From the images (photographs from the 


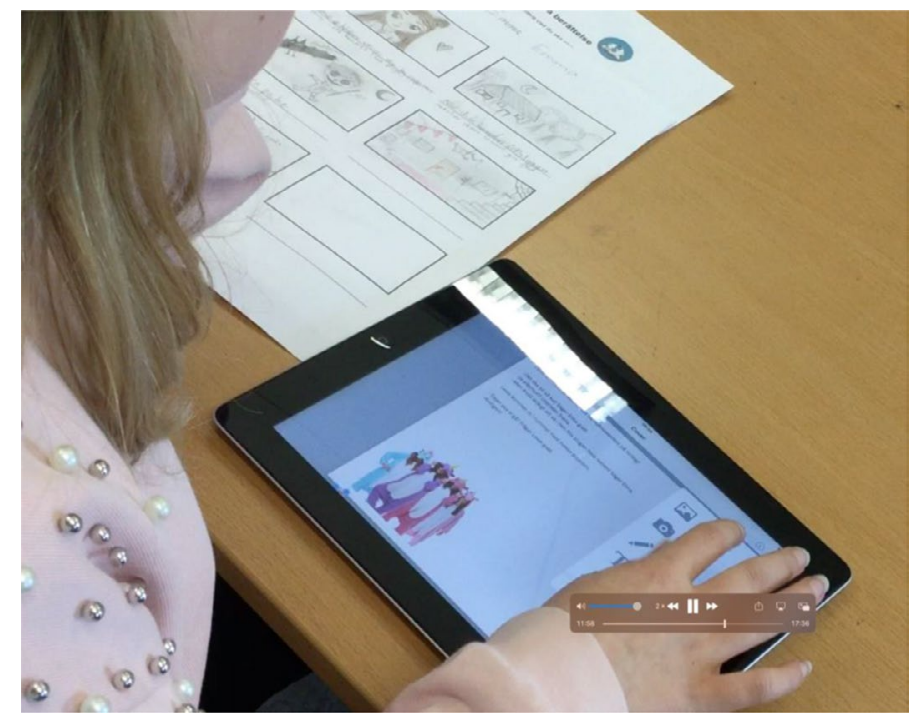

FIGURE 2 Ann's design process

Internet), Tiba arranged the pages in her story about a girl in love. On all pages, she used the same strategy.

Figure 3 illustrates an example of Tiba's design process.

Tiba explained that she used to watch reality shows at home, where she got inspiration for the story. She told me that she loved images and was used to searching for lovely images on the Internet. That was how she knew how to find exactly the images that she wanted for her story.

\section{Affordances and constraints of modes and media in the students' design process}

As described, the five students used digital and modal resources when designing text in unique ways. According to the students themselves, the former experience was crucial for choosing and using the modes' and media's affordances.

Tiba and Johan, who were not seen as competent writers, were very experienced in using various digital resources and modes when engaging with texts. They had no difficulties in using the affordances offered by both modes and media. They both knew how to write the correct search words to get images on the Internet, which meant that they easily could find and use images that suited what they wanted to express. Tiba loved images, she said. She preferred using images to writing when creating a story. She had many experiences interacting with digital images at home, she said. She watched many videos and reality TV shows as well. Tiba was confident in searching for images on the Internet. She knew exactly how to search, and how to change keywords to obtain a different selection of images, and she easily copied and pasted them into her text.

Johan, the only student who used several modes and several digital functions in the design process, was competent in moving around in the digital environment. He discovered the various opportunities offered by digital technologies, and he had the skills needed to utilise these opportunities. Johan knew how to take photographs and store the photos to use later in the text-design process. He showed his comfort using audio recordings in his text 


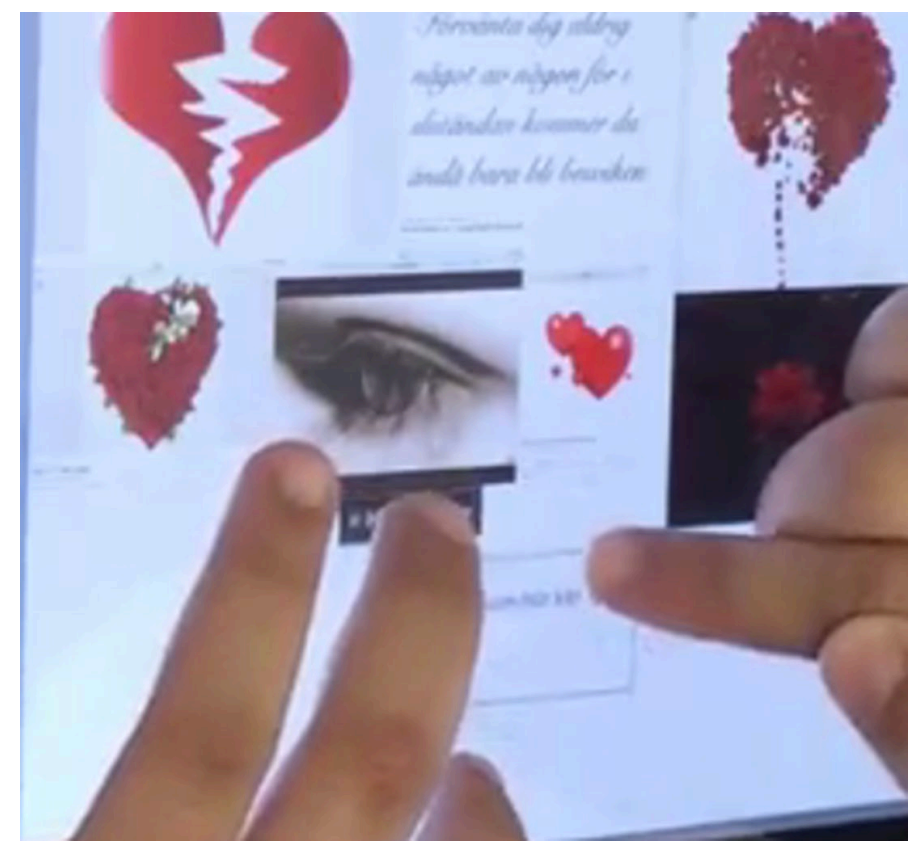

FIGURE 3 Tiba's design process

because he recorded his rap and downloaded a famous rap artist's song. He also knew how to use the video recording functions and how to edit video and images.

This knowledge and these skills, gained in informal settings, gave him several possibilities to express himself in various modes, and to make the story just as he wanted to, with videos and images that made the story more exciting, as he himself expressed it.

In contrast to Johan and Tiba, students Ann, Paula, and Fatima had little experience and knowledge regarding how to use the tablet's affordances. Both Ann and Paula encountered difficulties in finding images on the Internet. For Ann, this meant that she accepted to use the images she did find, changing her story to suit them, while Paula did not even try to find any images. Both Paula and Fatima started out writing, as they were accustomed to do when creating stories. Paula, a skilled and experienced writer, could write a story.

On the other hand, Fatima could not produce a story using the writing mode, due to her difficulties in writing. After discovering and finally accepting to use voice recording, Fatima created the digital story she wanted. Fatima had no previous experience using voice recording, and little experience using a tablet. However, she expressed that she was happy to tell a story, just as she had formulated it, in her head.

Using photographs from the Internet constrained Ann's design process because she could not find photographs that showed what she wanted to say. Accepting to use prefabricated images, rather than her drawings, forced her to change the story, which meant she could not represent the story as she originally intended. From these examples of students design processes, it became apparent that modes offer different potentials for meaningmaking and are used for different purposes. The mode of writing, for example, were mainly used for describing social relations and personal characteristics and images were used to illustrate people and environments. In the case of Johan, who used a combination of multiple modes and media functions, it became possible to represent meaning in many various ways. According to Johan, a story that includes several modes and media functions will be more exciting. Johan's text making process can serve as an example of text making process where modes are used complementary to create meaning in the text as a meaningful entity. 


\section{Resources and skills used in the students' design process}

As presented, students' prior knowledge about text making was crucial when students chose how to design their digital multimodal texts. This finding, in turn, meant that students with more experience and more knowledge of digital text creation had advantages over those students lacking these kinds of resources. Below is a list of students text-making practices, and skills observed in the data set.

- writing skills

- reading skills

- photography skills

- film skills

- film editing skills

- image search skills,

- audio recording skills

- a broader technical knowledge (e.g., how to download images, music, change sizes of images, use different font)

- a broader knowledge of digital multimodal text composition (e.g., knowing what modes to use for specific purposes, how modes interplay, and how to structure different texts to a whole)

To summarise the findings: (a) students' prior knowledge was crucial for mastering the digital and modal affordances offered when making digital stories; (b) multimodal digital text making requires particular digital and modal text-making knowledge, such as knowing how to search for and find images and other expressions on the Internet, knowing how to take photos and insert them into the story, knowing how to make voice recordings, knowing how to make and edit films and insert them into the story, and knowing how to arrange different text parts on the page; and (c) making multimodal digital texts in school offers increased opportunities for students to perform and succeed in text-making practices. Students with more digital text-making experiences, attained in informal settings, had advantages (e.g., knowing how to record video and search for images on the Internet) compared to those who did not.

\section{DISCUSSION}

This study aimed to find out how students design text, and identify what skills, knowledge, and resources they use in the process. The results indicate that students' prior experiences of digital text making were crucial for using and choosing the affordances offered by the available modes and media. Results also showed that digital multimodal text making is about combining modes and media functions to make a meaningful entity (e.g., Bezemer \& Kress, 2017). That students' experiences and background are meaningful for the expressions chosen in meaning-making is also emphasised by previous research (e.g., Kress, 2010). In this study, students were found to have various experiences of digital multimodal text making. Johan and Tiba were often engaged with digital and modal resources in informal settings (e.g., watching videos and posting images on social media). They efficiently utilised the tablet's affordances when designing the text (cf., Bezemer \& Kress, 2017). Tiba's ability to find images on the Internet, and Johan's use of photographs of his friends in his digital story, are two examples of meaning-making and learning that go beyond what happens inside the classroom, meaning-making and learning which, as Bezemer and Kress (2016) express, happen anywhere and at any time. As in Drewry et al. (2019), these two students 
had gained essential knowledge about contemporary meaning-making in informal settings. This type of learning can be explained as situated practice (NLG, 1996) and exemplifies how students' life experiences can become resources in the classroom environment (Lankshear \& Knobel, 2011). In other school literacy practices that require good writing skills, these students may not perform so well.

\section{Digital multimodal text making as a way to be a competent text maker}

Using a multimodal approach in literacy practices, and seeing learning as a situated practice, can promote a change in text-maker status for students who struggle with print literacy (Archer, 2014; Joucius, 2017). As in Joucius (2017), where a low-performing student became a high-performing student, and the traditional high-performing student showed limitations in his school performance, an indication of a shift in students' positions as text makers appeared in the present study. One example is Fatima, who could actually perform the task of creating a story when accessing digital and multimodal ways of designing texts. Other examples are Johan and Tiba, who became well-performing students when using digital and multimodal resources. For these three students, using digital and multimodal resources meant increased possibilities to create a digital story. For Ann and Paula, who already saw themselves as competent story writers, no actual change regarding task performance appeared.

\section{Learning by situated practice}

Johan and Tiba became engaged in the multiliteracy environment familiar to them from outside school. Students using available designs from informal settings outside of school, when designing text in school, aligns with previous research (Magnusson \& Godhe, 2019; Nagle \& Stooke, 2016; Ryan et al.., 2010). Learning by situated practice and critical framing (NLG, 1996) encouraged students in these studies to create their meanings from classroom practice, combined with diverse social and cultural contexts, to understand the world. For students in the 21st century, interpreting, understanding, and making various digital texts becomes crucial (Cope \& Kalantzis, 2015; Lankshear \& Knobel, 2011). Already in 1996, NLG argued for a literacy education built upon students' experiences, knowledge, interests, intentions, and purposes when designing texts in school. According to Bezemer and Kress (2017), a good starting point for an education that builds on students' previous knowledge is an examination of what text-making experiences, knowledge, and competencies students already possess upon entering the classroom. Providing access to multimodal, digital ways of learning for all students can help to bridge the gap between student's informal text-making activities and the school's formal text-making activities, as well as to reduce the digital divide among students (NLG, 1996; Rowsell et al., 2017).

\section{Implications for pedagogical practice}

This study provided examples of the differing conditions of students tasked with designing a digital multimodal text.

Findings in this study suggest that digital multimodal text making requires knowledge and skills beyond print-based text making, including photography skills, film skills, film editing skills, image search skills, and audio recording skills, and may involve other literacylearning disciplines, such as art and technology. These findings add to existing research that indicates the importance of education concerning modes and media unfamiliar to 
students, due to lack of experience (Dalton, 2014; Author; Sofkova Hashemi, 2018). A lack of digital experience often results in digital inequality (Author; Hernwall, 2010; OECD, 2015).

As indicated in this study, making multimodal digital texts in school can result in increased opportunities for students to perform and succeed in text-making practices. Allowing students to use multiple modes and media has been proven to improve students' abilities to perform school literacy tasks (Dalton, 2014; Drewry et al., 2019). This, in turn, can result in a shift in who is regarded as a competent text maker (Joucius, 2017). Such a shift might be relevant since contemporary text making requires many skills beyond knowing how to read and write.

Despite these arguments for introducing a multiliteracies pedagogy, and although 25 years have passed since New London Group's manifesto was published, the literacy practice in schools has not changed much. One of the barriers to overcome might be that multimodal meaning-making processes are still less valued and less recognised in assessment outcomes (Andersson, 2015; Magnusson \& Godhe, 2019; Mills, 2016; Silseth \& Gilje, 2019; Sofkova Hashemi, 2018; Tan et al., 2020). According to Andersson (2015), many teachers experiences that their knowledge about multimodal text creation is insufficient for adequately assessing multimodal texts. Reasoning from these considerations, it is evident that teachers need opportunities to develop multimodal meaning-making knowledge. However, promoting the pedagogy of multiliteracies should not confused with not valuing students' opportunities to become academic writers. A multimodal perspective is about valuing and recognising all the different ways of making meaning.

\section{CONFLICTS OF INTEREST}

There are no conflicts of interest to declare for this paper.

\section{DATA AVAILABILITY STATEMENT}

The data that support the findings of this study are available upon request from the corresponding author.

\section{ETHICS STATEMENT}

The research presented here followed the Swedish Research Council's ethical guidelines (Vetenskapsrådet, 2017). Students were informed about ethical considerations, including their voluntary participation, their right to end participation at any time, and their data's security and anonymity. Because the students were younger than 15 years old, their guardians signed informational letters that described the study's aim and the ethical considerations. As the study did not address sensitive matters like gender, sexuality, ethnicity, class, nationality, cultural identity, partnership status, faith, disability, political belief, or any other significant characteristic, no ethical review was done.

\section{ORCID}

Helene Dah/ström (D) https://orcid.org/0000-0001-9228-7130

\section{REFERENCES}

Adami, E. (2015). A social semiotic perspective on digital mobility. Media Education. Studies and Research, 6(2), 184-207.

Andersson, M. (2015). Berättandets möjligheter. Multimodala berättelser och estetiska lärprocesser. (Avhandling): Institutionen för konst, kommunikation och lärande [The possibilities of storytelling. Multimodal stories and aesthetic learning processes. (Dissertation): Department of Art, Communication and learning]. Luleå University of Technology. 
Archer, A. (2014). Power, social justice and multimodal pedagogies. In C. Jewitt (Ed.), The Routledge handbook of multimodal analysis (pp. 189-197). Routledge.

Auxier, B., \& Anderson, M. (2020). Parenting children in the age of screens. Pew Research center 2020.

Bezemer, J., \& Kress, G. (2016). Multimodality, learning and communication: A social semiotic frame. Routledge.

Bezemer, J., \& Kress, G. (2017). Young people, Facebook, and pedagogy: Recognising contemporary forms of multimodal text making. In M. Kontopodis (Ed.), Global youth in digital trajectories (pp. 22-38). Routledge.

Bezemer, J., \& Mavers, D. (2011). Multimodal transcription as academic practice: A social semiotic perspective. International Journal of Social Research Methodology, 14(3), 191-192. https://doi.org/10.1080/13645 579.2011 .563616

Björkvall, A., \& Engblom, C. (2010). Young children's exploration of semiotic resources during unofficial computer activities in the classroom. Journal of Early Childhood Literacy, 10, 271-293. https://doi.org/10.1177/16879 8410372159

Braun, V., \& Clarke, V. (2006). Using thematic analysis in psychology. Qualitative Research in Psychology, 3(2), 77-101. https://doi.org/10.1191/1478088706qp063oa

Cope, B., \& Kalantzis, M. (2009). "Multiliteracies": New literacies, new learning. Pedagogies: an International Journal, 4(3), 164-195. https://doi.org/10.1080/15544800903076044

Cope, B., \& Kalantzis, M. (red.) (2015). A pedagogy of multiliteracies: Learning by design. Palgrave Macmillan.

Dalton, B. (2014). Level up with multimodal composition in social studies. The Reading Teacher, 68(4), $296-302$. http://www.jstor.org/stable/24573868

Danielsson, K., \& Selander, S. (2016). Reading multimodal texts for learning - A model for cultivating multimodal literacy. Designs for Learning, 8(1), 25-36. https://doi.org/10.16993/dfl.72

Drewry, R. J., Cumming-Potvin, W. M., \& Maor, D. (2019). New approaches to literacy problems: Multiliteracies and inclusive pedagogies. Australian Journal of Teacher Education, 44(11), 61-78. https://doi.org/10.14221/ ajte.2019v44.n11.4

Edwards-Groves, C. J. (2011). The multimodal writing process: Changing practices in contemporary classrooms. Language and Education, 25(1), 49-64. https://doi.org/10.1080/09500782.2010.523468

Flewitt, R., Messer, D., \& Kucirkova, N. (2015). New directions for early literacy in a digital age: The iPad. Journal of Early Childhood Literacy, 15(3), 289-310. https://doi.org/10.1177/1468798414533560

Gee, J. P. (2004). Situated language and learning: A critique of traditional schooling. Routledge.

Grey, D. E. (2013). Doing research in the real world (3rd ed.). Sage.

Hernwall, P. (2010). Att ta i anspråk det okända - mot en flexibel digital grammatik [To use the unknown - Against a flexible digital grammar]. Utbildning \& Lärande, 4(1), 98-112.

Insulander, E. (2010). Tinget, rummet, besökaren: Om meningsskapande på museum (PhD dissertation, Institutionen för didaktik och pedagogiskt arbete, Stockholms universitet) [The room, the thing, the visitor: On meaning-making in museums. Department of didicics an pedagogical work]. http://urn.kb.se/resol ve?urn=urn:nbn:se:su:diva-37403

Jewitt, C. (2009). Technology, literacy and learning: A multimodal approach. Routledge.

Jewitt, C. (2012). Multimodal methods for researching digital technologies. In S. Price, C. Jewitt, \& B. Brown (Eds.), The Sage handbook of digital technology research (pp. 250-265). Sage.

Jewitt, C., Bezemer, J., \& O'Halloran, K. (2016). Introducing multimodality. Routledge.

Jocius, R. (2017). Good student/bad student: Situated identities in the figured worlds of school and creative multimodal production. Literacy Research: Theory, Method, and Practice, 66(1), 198-214. https://doi. org/10.1177/2381336917718177

Kress, G. (2009). Comments on Cope and Kalantzis pedagogies. An International Journal, 4(3), $205-212$.

Kress, G. (2010). Multimodality. A social semiotic approach to contemporary communication. Routledge.

Lankshear, C., \& Knobel, M. (2011). New literacies (3rd ed.). McGraw Hill Open University Press.

Magnusson, P., \& Godhe, A. L. (2019). Multimodality in language education-Implications for teaching. Designs for Learning, 11(1), 127-137. https://doi.org/10.16993/d.127

Mills, K. A. (2010). A review of the "digital turn" in the new literacy studies. Review of Educational Research, 80(2), 246-271. https://doi.org/10.3102/0034654310364401

Mills, K. A. (2011). "I'm making it different to the book": Transmediation in young children's print and digital practices. Australasian Journal of Early Childhood Education, 36(3), 56-65.

Mills, K. (2016). Literacy theories for the digital age: Social, critical, multimodal, spatial, material and sensory lenses (new perspectives on language and education). Multilingual Matters.

Nagle, J., \& Stooke, R. (2016). Railways, rebellions and rage against the machine: Adolescents' interests and meaning-making in creating multimodal identity texts. Literacy, 50, 158-165. https://doi.org/10.1111/lit.12081

New London Group. (1996). A pedagogy of multiliteracies: Designing social futures. Harvard Educational Review, 66, 60-92. https://doi.org/10.17763/haer.66.1.17370n67v22j160u

OECD. (2015). Students, computers and learning: Making the connection. PISA, OECD Publishing. https://doi. org/10.1787/9789264239555-en 
Olthouse, J. M. (2013). Multiliteracies theory and gifted education: Creating "smart spaces" in the language arts classroom. Gifted Child Today, 36(4), 247-253. https://doi.org/10.1177/1076217513497575

Pahl, K., \& Rowsell, J. (2019). Artifactual literacies: Every object tells a story. Teachers College Press.

Ritzhaupt, A. D., Cheng, L., Luo, W., \& Hohlfeld, T. N. (2020). The digital divide in formal educational settings: The past, present, and future relevance. In Handbook of research in educational communications and technology (pp. 483-504). . https://doi.org/10.1007/978-3-030-36119-8_23

Rowsell, J., Morrell, E., \& Alvermann, D. E. (2017). Confronting the digital divide: Debunking brave new world discourses. Reading Teacher, 71, 157-165. https://doi.org/10.1002/trtr.1603

Rowsell, J., \& Walsh, M. (2011). Rethinking literacy education in new times: Multimodality, multiliteracies, \& new literacies. Brock Education Journal, 21, 53.

Ryan, J., Scott, A., \& Walsh, M. (2010). Pedagogy in the multimodal classroom: An analysis of the challenges and opportunities for teachers. Teachers and Teaching: Theory and Practice, 16(4), 477-489. https://doi. org/10.1080/13540601003754871

Samuelsson, U. (2014). Digital (o) jämlikhet? IKT-användning i skolan and elevers tekniska Kapital [Digital (in) equality? ICT use in school and pupils' techno-logical capital] (Publication No. 23) [Doctoral dissertation]. School of Education and Communication Jönköping University.

Shanahan, L. (2012). Use of sound with digital text: Moving beyond sound as an add-on or decoration. Contemporary Issues in Technology and Teacher Education, 12(3). https://www.citejournal.org/volume-12/issue-3-12/engli sh-language-arts/use-of-sound-with-digital-text-moving-beyond-sound-as-an-add-on-or-decoration

Silseth, K., \& Gilje, Ø. (2019). Multimodal composition and assessment: A sociocultural perspective. Assessment in Education: Principles, Policy \& Practice, 26(1), 26-42. https://doi.org/10.1080/0969594X.2017.1297292

Smith, B. (2017). Composing across modes: A comparative analysis of adolescents' multimodal composing processes. Learning, Media and Technology, 42(3), 259-278. https://doi.org/10.1080/17439884.2016.1182924

Sofkova Hashemi, S. (2018). "You're meant to read the writing?": Young pupils negotiating meaning from digitally mediated multimodal texts. In C. Osbeck, A. Ingerman, \& S. Claesson (Eds.), Didactic classroom studies: $A$ potential research direction (pp. 87-110). Kriterium.

Svärdemo Åberg, E., \& Åkerfeldt, A. (2017). Design and recognition of multimodal texts: Selection of digital tools and modes on the basis of social and material premises. Journal of Computers in Education, 4(3), $283-306$. https://doi.org/10.1007/s40692-017-0088-3

Tan, L., Zammit, K., Dwarte, J., \& Gearside, A. (2020). Assessing multimodal literacies in practice: A critical review of its implementations in educational settings. Language and Education, 34(2), 97-114. https://doi. org/10.1080/09500782.2019.1708926

van Leeuwen, T. (2005). Introducing social semiotics. Routledge.

Vetenskapsrådet [Swedish Research Council]. (2017). God forskningssed [Good research practice].

How to cite this article: Dahlström, H. (2021). Students as digital multimodal text designers: A study of resources, affordances, and experiences. British Journal of Educational Technology, 00, 1-17. https://doi.org/10.1111/bjet.13171 